\title{
ANALISIS RASIO KEUANGAN TERHADAP KINERJA KEUANGAN PERUSAHAAN REAL ESTATE DAN PROPERTY YANG TERDAFTAR DI BURSA EFEK INDONESIA
}

\author{
Yenni Vera Fibriyanti \\ Fakultas Ekonomi, Universitas Islam Lamongan \\ yennivera@unisla.ac.id
}

\begin{abstract}
ABSTRAK
Penelitian pengaruh $C R, D R, D E R, T A T, R O E$ terhadap kinerja keuangan yang diproksikan dengan ROI pada perusahaan real estate dan property yang terdaftar di Bursa Efek Indonesia bertujuan untuk menganalisis pengaruh CR, DR, DER, TAT, ROE secara parsial, secara simultan dan yang paling dominan terhadap kinerja keuangan yang diproksikan dengan ROI pada perusahaan real estate dan property yang terdaftar di Bursa Efek Indonesia. Data diolah menggunakan program IBM SPSS Statistics 20. Teknik pengambilan sampel menggunakan metode purposive sampling yaitu sampel dipilih berdasarkan kriteria tertentu. Berdasarkan uji $t$ yang telah dilakukan dapat dibuktikan bahwa CR tidak berpengaruh secara parsial terhadap ROI. Hal ini dapat dilihat dari niali $t$ hitung sebesar 0,815 dengan tingkat signifikansi sebesar 0.417 > 0,05 . Variabel DR berpengaruh secara parsial terhadap ROI dengan nilai $t$ hitung sebesar 4,816 dan tingkat signifikansi sebesar 0,000 $<0,05$. Variabel DER berpengaruh secara parsial terhadap ROI dengan nilai t hitung sebesar -6,950 dan tingkat signifikansi sebesar 0,000 $<0,05$. Variabel TAT tidak berpengaruh secara parsial terhadap ROI dengan nilai $t$ hitung sebesar -1,542 dan tingkat signifikansi sebesar 0,589 > 0,05. Variabel ROE berpengaruh secara parsial terhadap ROI dengan nilai thitung 7,069 dan tingkat signifikansi sebesar 0,000 <0,05. Berdasarkan hasil uji $F$, dapat dilihat bahwa signifikansi $F<5 \%(0,000<0,05)$, yang artinya secara simultan variabel $C R, D R, D E R, T A T, R O E$ mempunyai pengaruh yang signifikan terhadap kinerja keuangan yang diproksikan dengan ROI pada perusahaan real estate dan property yang terdaftar di Bursa Efek Indonesia. Berdasarkan hasil regresi uji $t$, diketahui variabel ROE menunjukkan nilai $t$ hitung 7,069 dan tingkat signifikansi sebesar 0,000 $<0,05$ yang artinya variabel ROE berpengaruh paling dominan terhadap kinerja keuangan yang diproksikan dengan ROI pada perusahaan real estate dan property yang terdaftar di Bursa Efek Indonesia.
\end{abstract}

Kata Kunci: ROE, ROI, Kinerja Keuangan dan Perusahaan Real Estate dan Property

\section{PENDAHULUAN}

Dewasa ini seiring dengan berjalannya waktu, semakin banyak jumlah perusahaan yang ada di Indonesia. Setiap perusahaan pasti menginginkan usahanya dapat terus bertahan di tengah persaingan dan mengembangkan usaha untuk menjadi lebih baik. Era revolusi 4.0 saat ini menuntut seluruh sumber daya manusia untuk mengikuti perkembangan. Laju perkembangan internet juga semakin dirasakan oleh masyarakat setelah kehadiran era revolusi tersebut. 
Dengan menggunakan komputer ataupun telepon seluler yang terkoneksi dengan internet, manusia sudah mampu berkomunikasi dengan mengakses segala bentuk fasilitas yang ditawarkan. Dampaknya, terjadi disrupsi teknologi informasi dan komunikasi (TIK) yang sudah mulai berpengaruh pada tatanan kehidupan, di antaranya dunia industri, perusahaan dan lapangan pekerjaan.

Perkembangan dunia usaha di Indonesia khususnya pada perusahaan real estate dan property sangat pesat. Hal ini terlihat dari banyaknya perusahaan real estate dan property yang terus berkembang, baik perusahaan kecil, menengah, dan besar. Sektor property dan real estate menjadi sebuah ladang bisnis yang sangat menguntungkan karena beberapa pengusaha berhasil mempermainkan konsumen dengan rasa takut akan "kehabisan" tempat tinggal dikarenakan keterbatasan wilayah menjadi senjata ampuh bagi para pengusaha yang dapat menaikkan harga jual menjadi berkali-kali lipat sehingga sektor property dan real estate menjadi salah satu yang menarik untuk diteliti lebih dalam.

Untuk dapat membuat perusahaan terus berkembang dan maju, maka perusahaan harus terus mengikuti perkembangan terutama bidang ekonomi dan mengumpulkan informasi yang relevan dengan perusahaan. Dengan berkembangnya perusahaan tersebut, maka berkembang pula minat para investor, kreditor serta pihak-pihak yang mempunyai kepentingan pada perusahaan tersebut untuk berinvestasi. Para pihak yang mempunyai kepentingan pada perusahaan tentunya membutuhkan suatu informasi. Salah satu informasi yang dibutuhkan adalah terkait laporan keuangan perusahaan untuk mengetahui kinerja keuangan perusahaan. Dengan adanya laporan keuangan, dapat membantu stakeholder dalam pengambilan keputusan.

Berdasarkan latar belakang di atas, maka penelitian ini bertujuan (1) untuk menganalisis pengaruh $\mathrm{CR}$, DR, DER, TAT, ROE secara parsial terhadap kinerja keuangan yang diproksikan dengan ROI, (2) untuk menganalisis pengaruh $\mathrm{CR}$, DR, DER, TAT, ROE secara simultan terhadap kinerja keuangan yang diproksikan dengan ROI dan (3) untuk menganalisis rasio return on equity (ROE) sebagai variabel yang paling dominan berpengaruh terhadap kinerja keuangan yang diproksikan dengan ROI pada perusahaan real estate 
dan property yang terdaftar di Bursa Efek Indonesia.

\section{TINJAUAN PUSTAKA}

\subsection{Rasio Keuangan}

Debt ratio (DR) adalah melihat perbandingan utang perusahaan, yaitu diperoleh dari perbandingan total utang dibagi total aset (Fahmi, 2011 : 121). Rasio ini mengukur berapa besar aktiva perusahaan yang dibiayai oleh kreditur. Semakin tinggi debt ratio (DR) semakin besar jumlah modal pinjaman yang digunakan didalam menghasilkan keuntungan bagi perusahaan.

Menurut Hasanah,dkk (2017), Debt to equity ratio (DER) merupakan perbandingan antara hutang-hutang dan ekuitas dalam pendanaan perusahaan dan menunjukkan kemampuan modal sendiri, untuk memenuhi seluruh kewajibannya. Debt to equity ratio (DER) adalah ukuran yang dipakai dalam menganalisis laporan keuangan untuk memperlihatkan besarnya jaminan yang tersedia untuk kreditur (Fahmi, 2011 : 121).

Rasio return on equity (ROE) disebut juga dengan laba atas equity. Rasio ini mengkaji sejauh mana suatu perusahaan mempergunakan sumber daya yang dimiliki untuk mampu memberikan laba atas ekuitas (Fahmi,
2011 : 137). Return on equity yaitu kemampuan perusahaan dalam menghasilkan keuntungan dengan modal sendiri yang dimiliki, sehingga ROE ini ada yang menyebut sebagai profitabilitas modal sendiri (Sutrisno, 2009)

Menurut Kieso et,al (2014), Current ratio (CR) adalah pengukuran yang digunakan secara luas untuk mengevaluasi likuiditas perusahaan dan kemampuan membayar hutang jangka pendek. Current ratio (CR) adalah ukuran yang umum digunakan atas solvensi jangka pendek, kemampuan suatu perusahaan memenuhi kebutuhan suatu utang ketika jatuh tempo (Fahmi, 2011 : 121).

Menurut Kasmir (2012:185), Total assets turnover (TAT) merupakan rasio yang digunakan untuk mengukur perputaran semua aset yang dimiliki perusahaan dan mengukur berapa jumlah pendapatan yang diperoleh dari tiap rupiah aset. Rasio ini memiliki standar industri sebanyak 2 kali atau 200\% (Kasmir, 2012:187). Rasio total assets turnover (TAT) disebut juga dengan perputaran aset. Rasio ini sejauh mana keseluruhan aset yang dimiliki oleh perusahaan terjadi perputaran secara efektif (Fahmi, 2011: 121). 


\subsection{Kinerja Keuangan}

Kinerja keuangan adalah gambaran kondisi keuangan perusahaan pada suatu periode tertentu baik menyangkut aspek penghimpunan dana maupun penyaluran dana, yang biasanya diukur dengan indikator kecukupan modal, likuiditas, dan profitabilitas. Kinerja keuangan perusahaan merupakan prestasi yang dicapai perusahaan dalam suatu periode tertentu yang mencerminkan tingkat kesehatan perusahaan tersebut (Sutrisno, 2009:53).

Kinerja perusahaan merupakan suatu gambaran tentang kondisi keuangan suatu perusahaan yang dianalisis dengan alat-alat analisis keuangan, sehingga dapat diketahui mengenai baik buruknya keadaan keuangan suatu perusahaan yang mencerminkan prestasi kerja dalam periode tertentu. Hal ini sangat penting agar sumber daya digunakan secara optimal dalam menghadapi perubahan lingkungan (Fahmi, 2011:2).

\subsection{Perusahaan Real Estate dan}

\section{Property}

Potensi pertumbuhan berbagai sektor terutama sektor infrastruktur di Indonesia, dapat dikatakan cukup besar. Hal tersebut dibuktikan oleh pemerintah dengan adanya pembangunan infrastruktur-infrastruktur yang vital dan dapat menunjang perkembangan perekonomian di Indonesia (Fransiska, 2014). Pertumbuhan perekonomian di Indonesia salah satunya dapat dilihat dari sektor industri, baik itu industri kecil maupun industri besar. Salah satu sektor yang akan mendapatkan manfaat dari pembangunan infrastruktur ini adalah perusahaan di bidang property dan real estate (Hasanah, dkk, 2017).

Pertumbuhan sektor property dan real estate tentu saja akan tetap menarik minat para investor dikarenakan harga tanah dan bangunan yang cenderung terus naik, penawaran tanah bersifat tetap sedangkan permintaan selalu bertambah besar seiring dengan pertambahan jumlah penduduk serta bertambahnya kebutuhan manusia setiap tahunnya. Pertumbuhan property dan real estate di Indonesia didukung pula oleh para emiten di BEI yang bersifat likuid.

\subsection{Hipotesis}

Menurut Narimawati (2010) hipotesis merupakan asumsi atau dugaan sementara yang harus di uji kebenarannya dalam suatu analisis statistik. Berdasarkan landasan teori di 
atas, maka diperoleh hipotesis sebagai berikut:

$\mathrm{H}_{1}$ : Diduga CR, DR, DER, TAT, ROE berpengaruh secara parsial terhadap terhadap kinerja keuangan yang diproksikan dengan ROI pada perusahaan real estate dan property yang terdaftar di Bursa Efek Indonesia.

$\mathrm{H}_{2}$ : Diduga CR, DR, DER, TAT, ROE berpengaruh secara simultan terhadap kinerja keuangan yang diproksikan dengan ROI pada perusahaan real estate dan property yang terdaftar di Bursa Efek Indonesia.

$\mathrm{H}_{3}$ : Diduga return on equity (ROE) merupakan variabel yang paling dominan dalam mempengaruhi kinerja keuangaan yang diproksikan dengan ROI pada perusahaan real estate dan property yang terdaftar di Bursa Efek Indonesia.

\section{METODOLOGI PENELITIAN}

Penelitian ini menurut analisis datanya termasuk penelitian kuantitatif, yaitu penelitian yang menganalisis data yang berbentuk angka. Sedangkan menurut kegunaannya penelitian ini termasuk penelitian deskriptif, yaitu penelitian yang hendak membuat gambaran atau mencoba mancandra suatu peristiwa atau gejala secara sistematis, faktual dengan penyusunan yang akurat.

Populasi dalam penelitian ini adalah perusahaan real estate dan property yang terdaftar di Bursa Efek Indonesia (BEI). Adapun teknik pengambilan sampel dengan cara purposive sampling yaitu sampel dipilih berdasarkan kriteria tertentu. Kriteria yang dimaksud adalah: (1) Perusahaan real estate dan property yang terdaftar di Bursa Efek Indonesia dan laporan keuangannya telah dipublikasikan di Bursa Efek Indonesia (BEI) selama tahun 2013-2017. (2) Memiliki laporan keuangan yang lengkap (terutama item-item yang dapat dihitung dengan rasio keuangan). (3) Laporan keuangannya telah diaudit. (4) Berbentuk moneter rupiah. Teknik analisis data yang digunakan dalam penelitian ini meliputi uji asumsi klasik, analisis regresi berganda, uji hipotesis dengan menggunakan program IBM SPSS Statistics 20.

\section{HASIL DAN PEMBAHASAN}

\subsection{Uji Asumsi Klasik}

a. Analisis Uji Normalitas dalam penelitian ini, di hitung dengan 
menggunakan program IBM SPSS

Statistics 20. Adapun hasil analisis dapat disajikan sebagai berikut :

Normal P-P Plot of Regression Standardized Residual

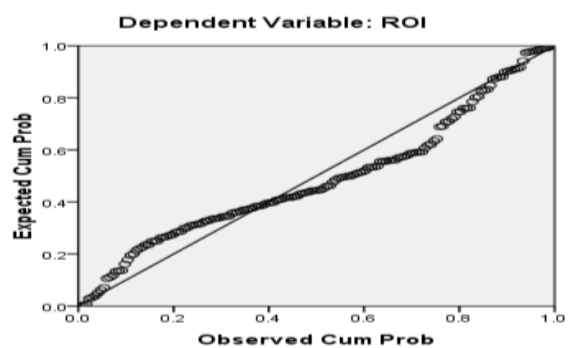

Gambar 1. Grafik Normalitas

Sumber : Output IBM SPSS Statistics 20

Grafik di atas menunjukkan bahwa data menyebar mengikuti garis normalitas. Hal ini menunjukkan bahwa data berdistribusi normal.

b. Analisis Uji Multikolinearitas dalam penelitian ini, di hitung dengan menggunakan program IBM SPSS Statistics 20.

Tabel 1.Hasil Uji Multikolinearitas

\begin{tabular}{|l|r|r|}
\hline \multirow{2}{*}{ Model } & \multicolumn{2}{|c|}{ Collinearity Statistics } \\
\cline { 2 - 3 } & Tolerance & \multicolumn{1}{c|}{ VIF } \\
\hline CR & .883 & 1.133 \\
DR & .275 & 3.638 \\
DER & .205 & 4.873 \\
TAT & .737 & 1.357 \\
ROE & .212 & 4.723 \\
\hline
\end{tabular}

Dari tabel di atas, terlihat untuk 5 variabel independen, angka VIF kurang dari 10 dan nilai tolerance mendekati 1 . Dari 5 rasio di atas dapat disimpulkan bahwa model regresi tersebut tidak terdapat problem multikolinieritas. Maka model regresi layak untuk dipakai.

c. Analisis Uji heteroskedastisitas dalam penelitian ini, di hitung dengan menggunakan program IBM SPSS Statistics 20. Adapun grafik hasil pengujian heterokesdastisitas pada grafik sebagai berikut:

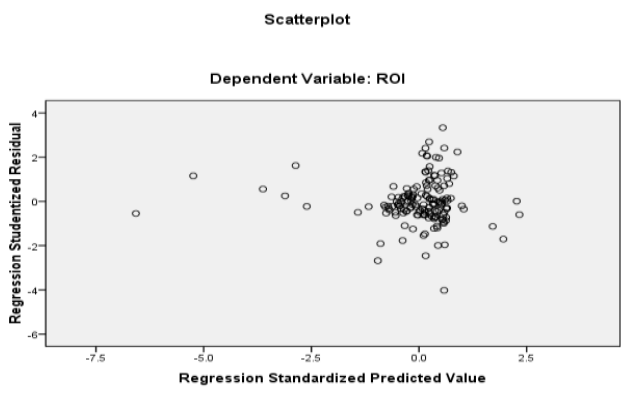

Gambar 2. Grafik Heterokedasitas Berdasarkan grafik di atas, dapat diketahui bahwa data (titik-titik) menyebar secara merata di atas dan di bawah garis nol dan tidak membentuk pola tertentu sehingga dapat disimpulkan bahwa pada uji regresi ini tidak terjadi problem heteroskedastisitas.

d. Untuk mengetahui adanya autokorelasi dalam suatu model regresi dapat dilihat dari hasil pengujian terhadap uji Durbin Watson. Dari tabel model summary diketahui angka DW sebesar 1,268 artinya regresi berganda dalam penelitian ini tidak ada autokorelasi. 
4.2 Uji Hipotesis Secara Parsial (t-Tes)

Adapun hasil analisis dapat disajikan sebagai berikut :

Tabel 2. Hasil Regresi uji t

\begin{tabular}{|cccccc}
\hline \multicolumn{5}{|c}{ Unstandardize } \\
d Coefficients \\
Model & B & Error & $\mathrm{t}$ & Sig. \\
1 (Const & & & & \\
ant) & -.003 & .006 & -.447 & .655 \\
CR & .000 & .000 & .815 & .417 \\
DR & .047 & .010 & 4.816 & .000 \\
DER & .000 & .000 & -6.950 & .000 \\
TAT & .005 & .009 & .542 & .589 \\
ROE & .007 & .001 & 7.069 & .000 \\
\hline
\end{tabular}

Berdasarkan tabel 2 di atas, maka persamaan regresi berganda sebagai berikut:

$\mathrm{ROI}=-0,003+0.000 \mathrm{CR}+0.047 \mathrm{DR}+$ 0.000 DER + 0.005 TAT + 0.007 ROE

Koefesien regresi CR, DR, DER, TAT, ROE bertanda positif, berarti hubungan antara CR, DER, TAT, ROE dengan ROI searah, artinya jika variabel tersebut meningkt, maka ROI juga meningkat, dan jika variabel tersebut turun maka ROI juga turun.

Dari tabel 1 di atas, menunjukkan bahwa nilai $\mathrm{t}$ hitung pada variabel current ratio $(\mathrm{CR})$ sebesar 0,815 dengan tingkat signifikansi sebesar $0.417>0,05$. Hal ini dapat disimpulkan bahwa variabel current ratio (CR) tidak berpengaruh secara parsial terhadap ROI.

Variabel debt ratio (DR) menunjukkan nilai t hitung sebesar 4,816 dengan tingkat signifikansi sebesar 0,000 $<0,05$. Hal ini dapat disimpulkan bahwa variabel DR berpengaruh secara parsial terhadap ROI.

Variabel debt to equity ratio (DER) menunjukkan nilai $t$ hitung sebesar $-6,950$ dengan tingkat signifikansi sebesar $0,000<0,05$. Hal ini dapat disimpulkan bahwa variabel DER berpengaruh secara parsial terhadap ROI.

Variabel total assets turnover (TAT) menunjukkan nilai $\mathrm{t}$ hitung sebesar -1,542 dengan tingkat signifikansi sebesar 0,589 >0,05. Hal ini dapat disimpukan bahwa variabel TAT tidak berpengaruh secara parsial terhadap ROI.

Variabel return on equity (ROE) menunjukkan nilai t hitung sebesar 7,069 dengan tingkat signifikansi sebesar 0,000 $<0,05$. Hal ini dapat disimpukan bahwa variabel ROE berpengaruh secara parsial terhadap ROI.

\subsection{Uji Hipotesis Secara Simultan}

Berdasarkan tabel di atas menunjukkan bahwa nilai $\mathrm{F}$ hitung 
sebesar 14.424 dengan nilai $\mathrm{p}$ value sebesar $0,000<0,05$, maka dapat disimpulkan bahwa CR, DR, DER, TAT, ROE, secara simultan berpengaruh terhadap variabel terikat yaitu ROI.

Tabel 3. Hasil Regresi uji F

\begin{tabular}{|c|c|c|}
\hline Model & F & Sig. \\
\hline Regression & 14.424 & $.000^{\mathrm{a}}$ \\
\hline
\end{tabular}

\subsection{Uji Hipotesis Secara Dominan}

Berdasarkan hasil analisis pada tabel 2 menunjukkan bahwa variabel return on equity (ROE) menunjukkan nilai $\mathrm{t}$ hitung terbesar yaitu, 7,069 dibandingkan dengan variabel lainnya dengan tingkat signifikansi sebesar 0,000 $<0,05$. Hal ini dapat disimpukan bahwa variabel ROE berpengaruh paling dominan terhadap return on invesment (ROI).

\subsection{Pembahasan}

Pembahasan mengenai DR, DER, ROE, CR, TAT terhadap kinerja keuangan pada perusahaan real estate dan property yang terdaftar di Bursa Efek Indonesia adalah sebagai berikut :

Variabel current ratio (CR) sebesar 0,815 dengan tingkat signifikansi sebesar $0.417>0,05$. Dengan demikian dapat disimpulkan bahwa variabel current ratio (CR) tidak berpengaruh secara parsial terhadap ROI. Hasil penelitian ini tidak sejalan dengan penelitian yang dilakukan Estirahayu, dkk (2014) yang menyatakan bahwa CR memberikan pengaruh yang signifikan terhadap ROI. Berdasarkan hasil tersebut manajer perusahaan perlu menjaga tingkat likuiditas (CR) perusahaan karena apabila tingkat likuiditas (CR) baik, perusahaan akan efektif dalam menghasilkan laba yang nantinya akan berdampak pada kinerja keuangan dan para investor akan percaya untuk berinvestasi pada perusahaan.

Variabel debt ratio menunjukkan nilai t hitung sebesar 4,816 dengan tingkat signifikansi sebesar 0,000 $<0,05$. Hal ini dapat disimpulkan bahwa variabel DR berpengaruh secara parsial terhadap ROI. Hasil ini mendukung penelitian yang dilakukan Farihah (2014) yang menyatakan bahwa DR berpengaruh negatif dan signifikan terhadap variabel ROA. Besar atau kecilnya modal pinjaman yang digunakan untuk investasi pada aktiva ternyata tidak menunjukkan hasil yang positif terhdap pertumbuhan laba. Dengan demikian, kreditur lebih menyukai DR yang rendah sebab tingkat keamannya semakin baik. 
Variabel debt to equity ratio (DER) menunjukkan nilai $\mathrm{t}$ hitung sebesar $-6,950$ dengan tingkat signifikansi sebesar $0,000<0,05$. Hal ini dapat disimpulkan bahwa variabel DER berpengaruh secara parsial terhadap ROI. Hasil ini mendukung penelitian yang dilakukan Estirahayu, dkk (2014) yang menyatakan bahwa DER mempunyai pengaruh yang signifikan terhadap ROI. Hasil analisis tersebut mengindikasikan bahwa semakin tinggi DER menunjukkan perusahaan dapat memberikan kepercayaan dan keyakinan kepada investor bahwa perusahaan dapat memanfaatkan semaksimal mungkin penggunaan modal asing untuk mengembangkan perusahaan. Sehingga hal ini sangat memungkinkan akan meningkatkan kinerja keuangan perusahaan, karena dengan modal yang besar maka kesempatan untuk meraih tingkat keuntungan juga besar.

Variabel total assets turnover (TAT) menunjukkan nilai $\mathrm{t}$ hitung sebesar -1,542 dengan tingkat signifikansi sebesar 0,589>0,05. Hal ini dapat disimpukan bahwa variabel TAT tidak berpengaruh secara parsial terhadap ROI. Hasil penelitian ini bertentangan dengan penelitian yang dilakukan Estirahayu, dkk (2014) yang menyatakan bahwa TAT memberikan pengaruh yang signifikan terhadap ROI dan ROE. Jika suatu perusahaan memiliki total asset turnover yang tinggi, maka perusahaan tersebut mampu mengelola aktivanya dengan efisien, sehingga perusahaan dapat meningkatkan ROI dan ROE. Karena perusahaan sudah dapat memanfaatkan aktiva tersebut untuk meningkatkan penjualan yang berpengaruh terhadap pendapatan. Kenaikan pendapatan dapat menaikkan profitabilitas yang berdampak pada kinerja keuangan perusahaan nantinya.

Variabel return on equity (ROE) menunjukkan nilai t hitung sebesar 7,069 dengan tingkat signifikansi sebesar 0,000 $<0,05$. Hal ini dapat disimpukan bahwa variabel ROE berpengaruh secara parsial terhadap ROI. Hasil ini mendukung penelitian yang dilakukan Ardian (2012) yang menyatakan bahwa ROE berpengaruh parsial terhadap ROI. ROE digunakan oleh investor untuk mengetahui kemampuan perusahaan dalam memperoleh laba bersih dalam kaitannya dengan pendapatan deviden. Semakin tinggi rasio ini menunjukkan laba bersih perusahaan yang semakin meningkat, sehingga meningkakan kinerja keuangan perusahaan. 
Hasil penelitian ini secara simultan konsisten dengan penelitian yang dilakukan oleh Ardian (2012), yang mengatakan bahwa current ratio, debt ratio, debt to equity ratio, total assete turnover, berpengaruh terhadap kinerja keuangan (return on invesmet). Artinya, semakin rendah rasio tersebut maka semakin baik karena aman bagi kreditur saat likuidasi.

\section{KESIMPULAN DAN SARAN}

\subsection{Kesimpulan}

Berdasarkan hasil penelitian dan pembahasan, maka kesimpulan yang didapatkan penulis adalah sebagai berikut :

1. Berdasarkan uji $t$ yang telah dilakukan dapat diketahui bahwa variabel CR, DR, DER, TAT, ROE berpengaruh secara parsial terhadap kinerja keuangan yang diproksikan dengan ROI pada perusahaan real estate dan property yang terdaftar di Bursa Efek Indonesia.

2. Berdasarkan hasil uji F memperlihatkan bahwa semua variabel independen yaitu $C R, D R$, DER, TAT, ROE secara bersama-sama atau simultan mempengaruhi kinerja keuangan yang diproksikan dengan ROI pada perusahaan real estate dan property yang terdaftar di Bursa Efek Indonesia. Hal ini bisa dilihat dari signifikansi $\mathrm{F}<5 \%(0,000<0,05)$.

3. Berdasarkan hasil regresi uji t yang telah dilakukan dapat diketahui bahwa variabel ROE berpengaruh paling dominan terhadap kinerja keuangan yang diproksikan dengan ROI pada perusahaan real estate dan property yang terdaftar di Bursa Efek Indonesia. Hal ini bisa dilihat dari nilai $\mathrm{t}$ hitung terbesar yaitu, 7,069 dibandingkan dengan variabel lainnya dengan tingkat signifikansi sebesar $0,000<0,05$.

\subsection{Saran}

Berdasarkan hasil analisis data dan kesimpulan diatas, maka penulis menyampaikan saran sebagai berikut :

1. Sebaiknya dilakukan penelitian lebih lanjut mengenai faktor-faktor yang mempengaruhi kinerja keuangan yaitu dengan penambahan variabel independen.

2. Agar mendapatkan perbandingan hasil, peneliti selanjutnya diharapkan untuk menambah periode penelitian atau mengubah sampel yang digunakan. 


\section{DAFTAR PUSTAKA}

Fahmi, Irham. 2011., Analisis Laporan

Keuangan. Penerbit, Alfabeta. Bandung.

Kieso, Donald E, et.al. 2014. Accounting Principles. Jakarta: Salemba Empat

Sutrisno. 2009. "Manajemen Keuangan Teori Konsep dan Aplikasi". Cetakan Ketujuh. Yogyakarta: Ekoisia.

Raharjo, dkk (2014). Pengaruh rasio CAR, NPL, LDR, BOPO, dan NIM terhadap Kinerja Bank Umum di Indonesia, Jurnal Ekonomi Manajemen Sumber Daya Vol. 15, No. 2, Desember 2014

Hasanah, dkk (2017). Analisis Kinerja Keuangan Perusahaan Real Estate Dan Property Yang Terdaftar Di Bursa Efek Indonesia Sebelum Dan Selama Pemerintahan Presiden Jokowi, Warta Ekonomi Vol. 07 No 17 Februari 2017

Rismansyah (2015). Pengaruh Rasio Keuangan Terhadap Return Saham Pada Perusahaan Propertydan Real Estate Yang Terdaftar Di Bursa Efek Indonesia (Bei), Jurnal Media Wahana Ekonomika, Vol. 12, No.3,Oktober 2015:80 - 95

Febrianty, dkk (2017). Kinerja Keuangan Perusahaan Property dan Real Estate di BEI Selama Periode 2012-2016 yang Termasuk di Indeks LQ45 (Studi pada Perusahaan yang Termasuk Pemeringkatan Indeks LQ45 Periode Februari 2017-Juli 2017),
Jurnal Manajemen dan Bisnis Sriwijaya Vol.15 (1), 2017

Esthirahayu, dkk (2014). Pengaruh Rasio Likuiditas, Rasio Leverage Dan Rasio Aktivitas Terhadap Kinerja Keuangan Perusahaan, Jurnal Administrasi Bisnis (JAB)| Vol. 8 No. 1 Februari 2014

Ardian (2014). Analisis Laporan Keuangan Untuk Menilai Kinerja Keuangan Perusahaan Real Estate Dan Property Yang Terdaftar Di Bursa Efek Indonesia, Tesis, Universitas Wijaya Kusuma Surabaya. 